\title{
THE IMPACT OF SEWAGE SLUDGE AND BIOMASS ASH FERTILIZATION ON THE YIELD, INCLUDING BIOMETRIC FEATURES AND PHYISIOLOGICAL PARAMETERS OF PLANTS OF TWO JERUSALEM ARTICHOKE (Helianthus tuberosus L.) CULTIVARS
}

\section{WPŁYW NAWOŻENIA OSADEM ŚCIEKOWYM I POPIOKEM Z BIOMASY NA PLONOWANIE ORAZ CECHY BIOMETRYCZNE I PARAMETRY FIZJOLOGICZNE ROŚLIN DWÓCH ODMIAN TOPINAMBURU (Helianthus tuberosus L.)}

\author{
Department of Bioenergetics and Food Analysis, University of Rzeszów, Poland \\ ${ }^{1}$ Department of Agronomy, West Pomeranian University of Technology, Szczecin, Poland
}

\begin{abstract}
Streszczenie. Topinambur należy do roślin, które mogą być materiałem do energetycznego wykorzystania. Celem przeprowadzonych badań była ocena wpływu nawożenia komunalnym osadem ściekowym i popiołem z biomasy drzew iglastych na plonowanie oraz cechy biometryczne i parametry fizjologiczne roślin dwóch odmian topinamburu (Helianthus tuberosus L.) - Albik i Gigant. Dwuletnie badania prowadzono na polu usytuowanym w miejscowości Ujkowice koło Przemyśla. Doświadczenie obejmowało następujące czynniki: 4 poziomy nawożenia popiołem z drzew iglastych jako biomasą, 2 poziomy nawożenia osadem ściekowym, 2 odmiany topinamburu (Helianthus tuberosus L.) - Gigant, Albik. W pierwszym roku po zastosowaniu osadów ściekowych w ilości $30,3 \mathrm{t} \cdot$ ha $^{-1}$ plon był mniejszy o około 0,8 t, zaś w drugim roku reakcja na nawożenie osadem była dodatnia. Zmiany plonu topinamburu w warunkach zróżnicowanego nawożenia osadem uzależnione były od długości pędów, wskaźnika LAI i SPAD. Nawożenie popiołem z biomasy spowodowało systematyczny wzrost plonu masy nadziemnej w 2013 roku. W następnym roku zbioru różnice były nieistotne. Wzrost plonu topinamburu pod wpływem nawożenia popiołem z biomasy związany był ze wzrostem długości pędów, zwiększeniem wartości wskaźnika LAI i SPAD. Nie stwierdzono istotnej interakcji pomiędzy nawożeniem organicznym a mineralnym. $Z$ badanych w doświadczeniu odmian większym plonem charakteryzowała się odmiana Albik. Polska odmiana Albik charakteryzowała się większą długością pędów, mniejszą średnicą pędów, wyższym indeksem LAI, znacznie większą wartością SPAD, zaś wskaźnik Fv/Fm był dla obu odmian zbliżony.
\end{abstract}

Key words: Jerusalem artichoke (Helianthus tuberosus L.), sewage sludge, biomass ash, yield, yield features, physiological parameters of plants.

Słowa kluczowe: topinambur (Helianthus tuberosus L.), osad ściekowy, popiół z biomasy, plon, cechy biometryczne, parametry fizjologiczne roślin.

\section{INTRODUCTION}

The turn of the 20th and 21st centuries witnessed intensified interests in the use of plantorigin raw materials for the production of renewable fuels. The combustion of biomass has become one of several ways of reducing $\mathrm{CO}_{2}$ emissions. The resulting ash can be usefully

Corresponding author - Adres do korespondencji: Grzegorz Hury, Department of Agronomy, West Pomeranian University of Technology, Szczecin, Pawła VI 3, 71-459, Szczecin, Poland, e-mail: Grzegorz.Hury@zut.edu.pl 
applied in crop fertilization, thus minimising its storage as a waste material. The deficiency in nitrogen and other organic substances can be supplemented using organic waste materials such as sewage sludge.

Its use for agricultural purposes is encouraged by the enormous content of calcium, magnesium and micronutrients as well as their positive impact on the soil physical properties. Studies conducted by Piekarczyk et al. (2011) as well as Meller and Bilenda (2012) demonstrate significant influence of biomass ash application on soils through the increased assimilation of available phosphorous, magnesium and potassium. A significant aspect of improved chemical properties of ash-treated soils is their reduced acidity along with an increased total sum of exchangeable alkalinity (Gibczyńska et al. 2009; Ciesielczuk et al. 2011; Meller and Bilenda 2012).

Organic contents of sludge encourage the formation of humus in soils, thus enhancing the crop growth (Szulc and Rutkowska 2002; Włodek 2007). The aforementioned results indicate that the application of biomass ash together with sewage sludge do significantly facilitate improvement of soil environmental properties as well as increased crop yields.

Jerusalem artichoke is one of such plants that can be put to energy use. While it possesses a strong root system, it also shades soils much faster than other root crops and can as such be cultivated on weak soils (Góral 1999). Jerusalem artichoke can also do well, for example, in substrates with lime flotation due to the storage of water and assimilates in its tubers and also reacts favourably in growth rates along with increasing doses of sewage sludge and nitrogen fertilization (Klimont 2004; Klimont and Bulińska-Radomska 2008). Jerusalem artichoke has no huge demands regarding to climatic requirements as it is tolerant to changing weather conditions and low temperatures, although a warm and humid weather is the most favourable for it. Available literature provides stem and tuber yields in very broad ranges, although the values for commercial plantations are reported in the range of $6-16 \mathrm{t} \cdot \mathrm{ha}^{-1}$ of stems, and dry matter $6-11 \mathrm{t} \cdot \mathrm{ha}^{-1}$ for tubers (Piskier and Sekutowski 2013). It is suitable for versatile uses for purposes of energy, feeds, food, herbal and soil reclamation functions. Having been dried, the aerial parts of artichoke can be directly burned in furnaces adapted for the combustion of biomass or in conjunction with coal.

The aim of the research was to determine the effect of fertilization with sewage sludge and ash from biomass conifers ash on yields and biometric and physiological parameters of two cultivars (Albik and Gigant) of Jerusalem artichoke (Helianthus tuberosus L.).

\section{MATERIAL AND METHODS}

\section{Conditions of the experiment conducting}

The two-year study, 2013 and 2014, was carried out in fields located in Ujkowice near Przemyśl $\left(49,85^{\circ} \mathrm{N}, 22,72^{\circ} \mathrm{E}\right)$. The trials covered 3 factors, as follows:

-4 levels of fertilization with biomass - ash from conifers $-0,4.28,8.57,12.85 \mathrm{t} \cdot \mathrm{ha}^{-1}$;

- 2 levels of fertilization with sewage sludge $-0,30.3 \mathrm{t} \cdot \mathrm{ha}^{-1}$;

- 2 cultivars of Jerusalem artichoke (Helianthus tuberosus L.) - Gigant and Albik.

The trial pattern was the split-plot $x$ split-block (SPSB) with 3 replications.

The plot size, as assumed for the study, was $35 \mathrm{~m}^{2}$ (7m in length and $5 \mathrm{~m}$ in width), with a harvest area of $24 \mathrm{~m}^{2}$ (6m in length and $4 \mathrm{~m}$ in width). Prior to the trials, an analysis of the 
soil, ash and sewage sludge was carried out to determine their parameters, the results of which are illustrated in tables 1-8. The soil, where the trials were conducted, was made of heavy loam. The agronomic soil category was heavy soil with the overall sum of fractions less than $0.02 \mathrm{~mm}$ amounting to $37.7 \%$. Based on the particle size, the soil can be categorised as heavy soil with its agricultural suitability classified as class IV according to the Polish Classification. The study began in September 2012. The land area was thus purposely prepared for the cultivation of Jerusalem artichoke intended for energy purposes. Having designated the area, samples of the top soil were obtained and three pits were dug to expose the soil profile. Spring field works, harrowing and dragging were preceded with herbicide treatments in early spring 2013 and after the emergence of Jerusalem artichoke. Soon after the emergence of couch grass, Roundup $360 \mathrm{SL}$ herbicide was applied at the 3-4 leaf stage at a dose of $3 \mathrm{dm}^{3} \cdot \mathrm{ha}^{-1}$ + adjuvant AS $500 \mathrm{SL}$ at 1-2 $\mathrm{dm}^{3} \cdot \mathrm{ha}^{-1}$. The field was ploughed in two weeks. The treatment was repeated after the emergence of Jerusalem artichoke using Fusilade Super $125 \mathrm{EC}$ at $2 \mathrm{dm}^{3} \cdot \mathrm{ha}^{-1}$.

\section{Methodology of analysis}

The height of plants was measured on 10 randomly selected plants from each plot. The measurements were carried out in early September in both years. The diameter of shoots was determined for each variant 20 times at a height of $10 \mathrm{~cm}$ above soil level. The intensity of the light phase photosynthesis was evaluated using the induced chlorophyll fluorescence method by determining the parameter value of $F_{V} / F_{M}$ (the maximum efficiency of the photochemical reaction of PS II was determined after the darkroom adaptation) using the Hansatech's (England) PEA field fluorometer. The time duration for measurement was 3 seconds, and 20 minutes for the darkroom adaptation with the light saturation intensity amounting to $3000 \mu \mathrm{mol} \cdot \mathrm{m}^{-2} \cdot \mathrm{s}^{-1}$. The number of repetitions for each variant was $\mathrm{n}=10$. Light transmission through the field was measured using Decagon's AccuPar ceptometer with an external sensor Licor's (USA) PAR LI 190 S.A. While 5 measurements were conducted in each plot, readings from 20 sensors were taken within each measurement.

The resulting data was presented as LAI parameters (Leaf Area Index - the ratio of plant's assimilation area to soil's surface area). The chlorophyll content was determined using the photo-optic method by means of Minolta's (USA) SPAD-502 analyser on 10 randomly selected plants from each variant. Ten measurements were taken from each plant. The fresh mass yield of plants was ascertained in three repetitions during the winters of 2013 and 2014. The plants were harvested using the fuel driven scythe, disregarding the outer rows and then weighed. The water content of the biomass was determined using the drying-weighing method and later converted to yield per dry mass.

\section{Statistical analysis}

The statistical analysis of results was performed using the 3-factorial analysis of variance for the SPSB design, separately for 2013 and 2014, with the number of replicates $n=3$. The multiple comparison of mean values was carried out using the Tukey's test at $\alpha=0.05$ level of significance. The Honestly Significant Difference $\left(\mathrm{HSD}_{0.05}\right)$ values provided in the tables were calculated for the following effects: main effect of sludge fertilization (NO), ash fertilization (NP) and cultivar $(\mathrm{O})$ as well as for interactions, which was statistically significant. The HSD for other 
insignificant interactions are not included in the tables. These calculations were supported by statistical package Anal var 5.3 (acc. to Franciszek Rudnicki, University of Science and Technology, Bydgoszcz, Poland). The relationship between dry matter yield and other features was analysed using Pearson's coefficient of linear correlation and simple regression analysis. These evaluations were carried out using STATISTICA v.12 software (StatSoft Inc. 2008). The statistical analysis of the results was performed using the 3-factorial analysis of variance.

\section{Climatic conditions}

Average atmospheric temperatures during the two growing seasons over the trial period (2013-2014) were comparable with mean data for the period 1971-2000 (Table 1).

Table 1. Average monthly atmospheric temperatures in ${ }^{\circ} \mathrm{C}(\mathrm{T})$ and sum of monthly precipitation in $\mathrm{mm}(\mathrm{O})$ during 2013-2014 as well as in multi-year period 1971-2000

Tabela 1. Średnie miesięczne temperatury powietrza $\mathrm{w}^{\circ} \mathrm{C}(\mathrm{T})$ i miesięczne sumy opadów $\mathrm{w} \mathrm{mm}(\mathrm{O})$ w latach 2013-2014 oraz w wieloleciu 1971-2000

\begin{tabular}{|c|c|c|c|c|c|c|}
\hline \multirow{3}{*}{ Month - Miesiąc } & \multicolumn{4}{|c|}{ Years - Lata } & \multirow{2}{*}{\multicolumn{2}{|c|}{$\begin{array}{c}\text { Mean for the years } \\
\text { Średnia wielolecia } \\
1971-2000\end{array}$}} \\
\hline & \multicolumn{2}{|c|}{2013} & \multicolumn{2}{|c|}{2014} & & \\
\hline & $T$ & $\mathrm{O}$ & $T$ & $\mathrm{O}$ & $\mathrm{T}$ & 0 \\
\hline April - Kwiecień & 8.6 & 50 & 9.2 & 50 & 8 & 50 \\
\hline May - Maj & 13.3 & 90 & 12.4 & 160 & 13 & 80 \\
\hline June - Czerwiec & 16.6 & 140 & 15.5 & 60 & 15 & 110 \\
\hline July - Lipiec & 17.9 & 80 & 18.5 & 120 & 18 & 100 \\
\hline August - Sierpień & 17.9 & 20 & 16.3 & & 18 & 70 \\
\hline September - Wrzesień & 11.0 & 70 & 13.9 & 60 & 14 & 70 \\
\hline October - Październik & 10.1 & 20 & 9.5 & 50 & 9 & 50 \\
\hline November - Listopad & 4.8 & 90 & 6.0 & 20 & 2 & 40 \\
\hline December - Grudzień & 1.4 & 20 & 0.5 & 40 & -1 & 40 \\
\hline $\begin{array}{l}\text { April - December } \\
\text { Kwiecień - Grudzień }\end{array}$ & 11.2 & 580 & 11.3 & 640 & 10.6 & 610 \\
\hline
\end{tabular}

Source - Źródło: Institute of Meteorology and Water Management in Warsaw for the Podkarpacie region - Materiały Instytutu Meteorologii i Gospodarki Wodnej w Warszawie dla regionu Podkarpacia.

The data showed that average precipitation in $2013(580 \mathrm{~mm})$ was lower than the multi-year records of $610 \mathrm{~mm}$, but higher $(640 \mathrm{~mm})$ in 2014 . The highest rainfall of $140 \mathrm{~mm}$ and $120 \mathrm{~mm}$ was noted in the months of June 2013 and July 2014, respectively.

The average air temperatures for the first growing season (2013) of $11.2^{\circ} \mathrm{C}$ were close to the average for the second growing season $\left(11.3^{\circ} \mathrm{C}\right)$ but slightly higher than the multi-year average $\left(10.6^{\circ} \mathrm{C}\right)$. The average monthly air temperatures both for the beginning the growing season were similar to the multi-year figures. The other months were characterized by significantly lower rainfalls. The mean temperatures recorded from October to December were higher than the multi-year average by $2^{\circ} \mathrm{C}$. The mean monthly temperature of $11.3^{\circ} \mathrm{C}$ in 2014 was higher than the multi-year by $0.7^{\circ} \mathrm{C}$. High air temperatures for November were favourable for vegetative growth, thus creating conditions suitable for winter cropping. Prevailing weather conditions for December were no threats to wintering plants. Warm and sunny weather conditions in March helped to dry the fields, thus heating up the soil. The dampness of the topsoil at the beginning of the growing season ensured the water needs of plants. April's prevailing weather conditions were also favourable for agriculture. Prevailing agro-meteorological 
conditions in May varied. Plants growth and development were somewhat hindered by the periodic chills. Rainfalls within the month that were at times quite intense and torrential in south-east Poland, led to the excessive soil moisture and light flooding hampered the field work. July rainfalls had positive impact on the topsoil's moisture status as well as on root crop development (Table 1).

\section{RESULTS AND DISCUSSION}

\section{Dry matter yield}

The Jerusalem artichoke tubers planted in the spring of 2013 germinated evenly. The plant density was consistent with that established while planning the trials. No loss of plants was observed on the experimental plot in the spring following winter of 2013/2014.

The application of sludge at a rate of $30.3 \mathrm{t} \cdot \mathrm{ha}^{-1}$ relative to the control variant resulted in significant decline in Jerusalem artichoke's dry matter yield by $0.87 \mathrm{t} \cdot \mathrm{ha}^{-1}$ (Table 2 ). While the yields were about $0.8 \mathrm{t}$ lower in the first year of application, their response to sludge fertilization was positive in the second year. A varied reaction of the cultivars under study was observed. The Dutch cultivar Gigant was characterized by higher yields than the Polish Albik cv. grown in the control plot. The situation was the other way round following the application of sewage sludge with the Albik cv. giving higher yields. This indicates the much stronger negative reaction of Gigant cv. The results obtained in the second year indicate the non-uniform reaction of plants to the sludge application in the first year, but it varied in respect of the cultivars. There was a significant increase in the yield of Gigant cv., while Albik cv. showed no response. The Albik cv. was characterized by higher yields. If the average yields in the second year of study of the variant with sewage sludge fertilization was considered, the difference turned out much smaller. The Gigant cv. seems to have much higher fertilizer demands than the Polish cultivar.

Kalembasa and Malinowska (2007) as well as Góral (1999) report that the use of compost in very low dosages may result in insufficient effects. Although researches by Kalembasa and Malinowska (2007) were conducted in respect of Mischanthus, it was a plant also cultivated for energy purposes, with comparable yield levels. The use of sewage sludge in conjunction with mineral fertilizers, improves the efficiency of sewage sludge. Research on the use of biomass ash was in recent years conducted in several centres in country and abroad (Bakisgan et al. 2007; Meller et al. 2009; Ciesielczuk et al. 2011; James et al. 2012; Meller and Bilenda 2012; Piekarczyk 2013; Stankowski et al. 2014). The dosage of biomass ash applied in the various studies varied a lot. This was mainly dependent on the content of available potassium and heavy metals. Stankowski et al. (2014) carried out studies using ash, in which the potassium content was $8.9 \%$, thus significantly limiting its dosage. Biomass ash fertilizer abundant in potassium, which is deficient in sewage sludge, was applied as the second factor in the study. Biomass ash fertilization in the first year (direct soil application) resulted in systematic increase in yields from 3.89 to $4.57 \mathrm{t} \cdot \mathrm{ha}^{-1}$. No yield differentiations were observed in the second year, as they were much less and incidental. Based on earlier studies (Meller and Bilenda 2012), it can be stated that there was considerable increase at doses far exceeding those applied in the current tests. No impacts on yields were observed when the dose rate was about 2.0 tons (Stankowski et al. 2014). There were neither differences in responses to ash fertilization by the cultivars studied, nor were there any interactions between 
ash and sludge fertilization in both years. Although the highest-yielding cultivar was Albik cv., the difference in the first year was relatively low $\left(0.24 t \cdot h^{-1}\right)$, but was decisively higher in the second year $\left(2,73 \mathrm{t} \cdot \mathrm{ha}^{-1}\right)$. Increased yield of Jerusalem artichoke in the first year was mainly due to the prolongation of shoots. Yields of Jerusalem artichoke were higher in the second year of tubers being planted with the average yield values reaching 4.17 and $7.71 \mathrm{t} \cdot \mathrm{ha}^{-1}$, respectively.

Table 2. Impact of sewage sludge (NO) and biomass ash (NP) fertilization on yields [t $\left.\cdot \mathrm{ha}^{-1} \mathrm{DM}\right] \mathrm{of}^{\mathrm{N}}$ Jerusalem artichoke cultivars (O)

Tabela 2. Wpływ nawożenia osadem ściekowym (NO) i popiołem z biomasy (NP) na plon [t $\cdot$ ha ${ }^{-1} \mathrm{~s} . \mathrm{m}$.] odmian (O) topinamburu

\begin{tabular}{|c|c|c|c|c|c|c|c|}
\hline \multirow{2}{*}{$\begin{array}{l}\text { Year } \\
\text { Rok }\end{array}$} & \multicolumn{2}{|l|}{ Factor - Czynnik } & \multicolumn{4}{|c|}{$\begin{array}{l}\text { Ash fertilization - Nawożenie popiołem } \\
{\left[\mathrm{t} \cdot \mathrm{ha}^{-1}\right]}\end{array}$} & \multirow{2}{*}{$\begin{array}{l}\text { Average } \\
\text { Średnia }\end{array}$} \\
\hline & $\begin{array}{l}\text { sludge - osad } \\
{\left[\mathrm{t} \cdot \mathrm{ha}^{-1}\right]}\end{array}$ & $\begin{array}{l}\text { cultivar } \\
\text { odmiana }\end{array}$ & 0 & 4.3 & 8.6 & 12.8 & \\
\hline \multirow{10}{*}{2013} & \multirow{3}{*}{0} & Gigant & 4.38 & 4.56 & 4.68 & 5.26 & 4.72 \\
\hline & & Albik & 4.52 & 4.25 & 4.35 & 4.85 & 4.49 \\
\hline & & $\begin{array}{l}\text { average } \\
\text { średnia }\end{array}$ & 4.45 & 4.41 & 4.51 & 5.06 & 4.61 \\
\hline & \multirow{3}{*}{30.3} & Gigant & 3.24 & 3.20 & 3.34 & 3.73 & 3.38 \\
\hline & & Albik & 3.41 & 4.00 & 4.51 & 4.46 & 4.10 \\
\hline & & $\begin{array}{l}\text { average } \\
\text { średnia }\end{array}$ & 3.32 & 3.60 & 3.93 & 4.09 & 3.74 \\
\hline & \multirow{2}{*}{ average - średnia } & Gigant & 3.81 & 3.88 & 4.01 & 4.49 & 4.05 \\
\hline & & Albik & 3.97 & 4.13 & 4.43 & 4.66 & 4.29 \\
\hline & \multicolumn{2}{|c|}{ total average - średnia ogólna } & 3.89 & 4.00 & 4.22 & 4.57 & 4.17 \\
\hline & \multicolumn{2}{|c|}{$\mathrm{HSD}_{0.05}$ for $-\mathrm{HSD}_{0,05}$ dla } & \multicolumn{5}{|c|}{$\mathrm{NO}-0.389, \mathrm{NP}-0.479, \mathrm{O}-0.188, \mathrm{O} / \mathrm{NO}-0.195$} \\
\hline \multirow{10}{*}{2014} & \multirow{3}{*}{0} & Gigant & 5.65 & 5.13 & 5.31 & 5.72 & 5.45 \\
\hline & & Albik & 9.10 & 9.26 & 9.01 & 9.40 & 9.19 \\
\hline & & $\begin{array}{l}\text { average } \\
\text { średnia }\end{array}$ & 7.37 & 7.20 & 7.16 & 7.56 & 7.32 \\
\hline & \multirow{3}{*}{30.3} & Gigant & 7.21 & 7.21 & 7.12 & 7.40 & 7.24 \\
\hline & & Albik & 9.01 & 8.56 & 9.30 & 8.92 & 8.95 \\
\hline & & $\begin{array}{l}\text { average } \\
\text { średnia }\end{array}$ & 8.11 & 7.89 & 8.21 & 8.16 & 8.09 \\
\hline & \multirow{2}{*}{ average - średnia } & Gigant & 6.43 & 6.17 & 6.22 & 6.56 & 6.34 \\
\hline & & Albik & 9.06 & 8.91 & 9.16 & 9.16 & 9.07 \\
\hline & \multicolumn{2}{|c|}{ total average - średnia ogólna } & 7.74 & 7.54 & 7.69 & 7.86 & 7.71 \\
\hline & \multicolumn{2}{|c|}{$\mathrm{HSD}_{0.05}$ for $-\mathrm{HSD}_{0,05}$ dla } & $\mathrm{NO}-0$. & $P-n . s$ & 0.344 & $0-0.4$ & \\
\hline
\end{tabular}

n.s. - not significant difference - różnica nieistotna.

Changes in yield size of Jerusalem artichoke depended mainly on the plant height, SPAD and LAI, as can be seen from the significant correlation coefficient in both years. A significant, positive dependence between yields and Fv/Fm indicator was also confirmed in the second year (Table 2). Kuś and Faber (2009) reported the average yield of dry matter of aerial parts of Jerusalem artichoke cultivated on sandy soils for three years, which amounted to about $9 \mathrm{t} \cdot \mathrm{ha}^{-1}$. Chołuj et al. (2008) obtained similar results, namely $8 \mathrm{t} \cdot \mathrm{ha}^{-1}$ during their three-year tests. Piskier (2006, 2009), on the other hand, obtained about 8.5 and 6 tons of stems per hectare on average for two years from cultivations on semi-compact soils with granulometric composition of loam, class IVa. It can therefore be concluded that yields obtained from trials carried out in Podkarpacie foothill regions were within the range of yields obtained in other regions in Poland. 


\section{Height of shoots}

While evaluating the morphological features that determine the yield size of 10 genotypes of Jerusalem artichoke selected from IHAR gene bank, Góral (1999a) showed that the tested clones varied significantly in respect of plants' height and number of shoots. From amongst the families studied by Góral (1999a), the best objects were selected in order to create Jerusalem artichoke's cultivars Rubik and Albik, which have been entered in the Register of Original Cultivars COBORU.

The height of Jerusalem artichoke's shoots varied in subsequent years of the study. They attained an average height of $177 \mathrm{~cm}$ and $191 \mathrm{~cm}$ in the first and second year, respectively (Table 3). The application of sewage sludge in 2013 resulted in lower shoot heights by about $16 \mathrm{~cm}$. The height of shoots for the two tested cultivars in the control variant was similar, reaching $183 \mathrm{~cm}$ and $188 \mathrm{~cm}$ for the Gigant cv. and Albik cv., respectively. However, Gigant cv. turned out to be decisively lower than Albik cv. by almost $30 \mathrm{~cm}$ following the application of sewage sludge. Similar differences were not, however, observed in the second year, regardless of the cultivar. While Gigant cv. was shorter than Albik cv. in the control variant, their heights were similar in the fertilized variant. Varying the ash fertilization resulted in increased heights of the shoots. Significant variations were observed when the dosage was increased from 0 to $8.6 \mathrm{t} \cdot \mathrm{ha}^{-1}$. Further increase in fertilizer rate had no impact on the feature under study. The height of shoots in the second year of cultivation (2014) was approximately the same, regardless of the rate of biomass ash fertilization. The average height of Albik cv. shoots was higher than for the Gigant cv. The differences in height reached $15 \mathrm{~cm}$ and $18 \mathrm{~cm}$ for the first and second year of cultivation, respectively.

Table 3. Impact of sewage sludge (NO) and biomass ash (NP) on the height of shoots [cm] of Jerusalem artichoke cultivars $(\mathrm{O})$

Tabela 3. Wpływ nawożenia osadem ściekowym (NO) i popiołem z biomasy (NP) na wysokość pędów [cm] odmian (O) topinamburu

\begin{tabular}{|c|c|c|c|c|c|c|c|}
\hline \multirow{2}{*}{$\begin{array}{l}\text { Year } \\
\text { Rok }\end{array}$} & \multicolumn{2}{|c|}{ Factor - Czynnik } & \multicolumn{4}{|c|}{$\begin{array}{c}\text { Ash fertilization - Nawożenie popiołem } \\
{\left[\mathrm{t} \cdot \mathrm{ha}^{-1}\right]}\end{array}$} & \multirow{2}{*}{$\begin{array}{l}\text { Average } \\
\text { Średnia }\end{array}$} \\
\hline & $\begin{array}{c}\text { sludge - osad } \\
{\left[\mathrm{t} \cdot \mathrm{ha}^{-1}\right]}\end{array}$ & $\begin{array}{c}\text { cultivar } \\
\text { odmiana }\end{array}$ & 0 & 4.3 & 8.6 & 12.8 & \\
\hline \multirow{10}{*}{2013} & \multirow{3}{*}{0} & Gigant & 172 & 180 & 189 & 190 & 183 \\
\hline & & Albik & 177 & 181 & 188 & 204 & 188 \\
\hline & & $\begin{array}{l}\text { average } \\
\text { średnia }\end{array}$ & 175 & 181 & 189 & 197 & 185 \\
\hline & \multirow{3}{*}{30.3} & Gigant & 147 & 154 & 159 & 165 & 156 \\
\hline & & Albik & 181 & 180 & 187 & 177 & 182 \\
\hline & & $\begin{array}{l}\text { average } \\
\text { średnia }\end{array}$ & 164 & 167 & 173 & 171 & 169 \\
\hline & \multirow{2}{*}{ average - średnia } & Gigant & 160 & 167 & 174 & 178 & 170 \\
\hline & & Albik & 179 & 181 & 188 & 191 & 185 \\
\hline & \multicolumn{2}{|c|}{ total avaerage - średnia ogólna } & 169 & 174 & 181 & 184 & 177 \\
\hline & \multicolumn{2}{|c|}{$\mathrm{HSD}_{0.05}$ for $-\mathrm{HSD}_{0,05}$ dla } & $\mathrm{NO}-1$ & $2-12$ & $6.7, \mathrm{O} /$ & 9.5 & \\
\hline \multirow{10}{*}{2014} & \multirow[t]{3}{*}{ 1) } & Gigant & 172 & 168 & 170 & 167 & 170 \\
\hline & & Albik & 199 & 208 & 209 & 204 & 205 \\
\hline & & $\begin{array}{l}\text { average } \\
\text { średnia }\end{array}$ & 186 & 188 & 190 & 186 & 187 \\
\hline & \multirow{3}{*}{30.3} & Gigant & 198 & 200 & 182 & 200 & 195 \\
\hline & & Albik & 197 & 193 & 193 & 192 & 194 \\
\hline & & $\begin{array}{l}\text { average } \\
\text { średnia }\end{array}$ & 198 & 197 & 188 & 196 & 194 \\
\hline & \multirow{2}{*}{ average - średnia } & Gigant & 185 & 184 & 176 & 184 & 182 \\
\hline & & Albik & 198 & 201 & 201 & 198 & 200 \\
\hline & \multicolumn{2}{|c|}{ total average - średnia ogólna } & 192 & 193 & 189 & 191 & 191 \\
\hline & \multicolumn{2}{|c|}{$\mathrm{HSD}_{0.05}$ for $-\mathrm{HSD}_{0,05}$ dla } & $\mathrm{NO}-\mathrm{n}$ & - n.s. & $1.3, \mathrm{O} / \mathrm{I}$ & 6.9 & \\
\hline
\end{tabular}

n.s. - not significant difference - różnica nieistotna. 


\section{Diameter of shoots}

The average thickness of shoots (Table 4) was higher by about $8 \%$ in the first rather than in the second year of study. This was associated with greater number of shoots per unit area as well as greater heights. A tendency of plants towards having smaller diameters of shoots was observed in the variant with sewage sludge in both years of study, but such difference was not statistically proven. A distinctive response of cultivars to sludge fertilization was observed. The Gigant cv. was noted for having thicker shoots than the Albik cv. in the sludge free variant. The thickness of shoots was comparable for both cultivars, wherever the sewage sludge was applied. This pattern was prevalent in the two-year period. Biomass ash fertilization had no influence on the factor in question. The differences were insignificant and sporadic in nature. The lack of any link between rate of biomass ash fertilization and shoots' thickness was noticeable. No significant differences in shoots diameters were observed between the tested cultivars, although Gigant cv. showed tendency to produce thicker shoots. This was, however, due to their greater diameter of shoots in the sludge free variant.

Table 4. Impact of sewage sludge (NO) and biomass ash (NP) fertilization on shoot diameters [cm] of Jerusalem artichoke $(O)$ cultivars

Tabela 4. Wpływ nawożenia osadem ściekowym (NO) i popiołem z biomasy (NP) na średnicę pędów [cm] odmian $(\mathrm{O})$ topinamburu

\begin{tabular}{|c|c|c|c|c|c|c|c|}
\hline \multirow{2}{*}{$\begin{array}{l}\text { Year } \\
\text { Rok }\end{array}$} & \multicolumn{2}{|c|}{ Factor - Czynnik } & \multicolumn{4}{|c|}{$\begin{array}{l}\text { Ash fertilization - Nawożenie popiołem } \\
{\left[\mathrm{t} \cdot \mathrm{ha}^{-1}\right]}\end{array}$} & \multirow{2}{*}{$\begin{array}{l}\text { Average } \\
\text { Średnia }\end{array}$} \\
\hline & $\begin{array}{c}\text { sludge - osad } \\
{\left[\mathrm{t} \cdot \mathrm{ha}^{-1}\right]}\end{array}$ & $\begin{array}{l}\text { cultivar } \\
\text { odmiana }\end{array}$ & 0 & 4.3 & 8.6 & 12.8 & \\
\hline \multirow{10}{*}{2013} & \multirow{3}{*}{0} & Gigant & 1.60 & 1.57 & 1.53 & 1.57 & 1.57 \\
\hline & & Albik & 1.30 & 1.20 & 1.10 & 1.20 & 1.20 \\
\hline & & $\begin{array}{l}\text { average } \\
\text { średnia }\end{array}$ & 1.45 & 1.38 & 1.32 & 1.38 & 1.38 \\
\hline & \multirow{3}{*}{30.3} & Gigant & 1.30 & 1.40 & 1.17 & 1.20 & 1.27 \\
\hline & & Albik & 1.32 & 1.20 & 1.30 & 1.30 & 1.28 \\
\hline & & $\begin{array}{l}\text { average } \\
\text { średnia }\end{array}$ & 1.31 & 1.30 & 1.23 & 1.25 & 1.27 \\
\hline & \multirow{2}{*}{ average - średnia } & Gigant & 1.45 & 1.48 & 1.35 & 1.38 & 1.42 \\
\hline & & Albik & 1.31 & 1.20 & 1.20 & 1.25 & 1.24 \\
\hline & \multicolumn{2}{|c|}{ total average - średnia ogólna } & 1.38 & 1.34 & 1.28 & 1.32 & 1.33 \\
\hline & \multicolumn{2}{|c|}{$\mathrm{HSD}_{0.05}$ for $-\mathrm{HSD}_{0,05}$ dla } & \multicolumn{4}{|c|}{$\mathrm{NO}-$ n.s., NP - n.s., O - 0.131, O/NO - 0.181} & \\
\hline \multirow{10}{*}{2014} & \multirow[t]{3}{*}{ (n) } & Gigant & 1.30 & 1.41 & 1.31 & 1.39 & 1.36 \\
\hline & & Albik & 1.30 & 1.02 & 1.11 & 1.19 & 1.15 \\
\hline & & $\begin{array}{l}\text { average } \\
\text { średnia }\end{array}$ & 1.30 & 1.22 & 1.21 & 1.29 & 1.26 \\
\hline & \multirow{3}{*}{30.3} & Gigant & 1.30 & 1.21 & 1.02 & 1.20 & 1.18 \\
\hline & & Albik & 1.10 & 1.21 & 1.29 & 1.30 & 1.22 \\
\hline & & $\begin{array}{l}\text { average } \\
\text { średnia }\end{array}$ & 1.21 & 1.19 & 1.15 & 1.25 & 1.21 \\
\hline & \multirow{2}{*}{ average - średnia } & Gigant & 1.30 & 1.31 & 1.15 & 1.30 & 1.26 \\
\hline & & Albik & 1.20 & 1.09 & 1.20 & 1.25 & 1.19 \\
\hline & \multicolumn{2}{|c|}{ total average - średnia ogólna } & 1.25 & 1.20 & 1.18 & 1.27 & 1.23 \\
\hline & \multicolumn{2}{|c|}{$\mathrm{HSD}_{0.05}$ for $-\mathrm{HSD}_{0,05}$ dla } & $\mathrm{NO}-\mathrm{n}$. & -n.s., & $. \mathrm{O} / \mathrm{N}$ & .172 & \\
\hline
\end{tabular}

n.s. - not significant difference - różnica nieistotna.

\section{Leaf Area Index (LAl)}

The leaf area index (LAl) that indicates the ratio of the leaf surface area to that of the soil is expressed in $\mathrm{m}^{2} \cdot \mathrm{m}^{-2}$. Augustynowicz et al. (2010) state that the use of sewage sludge fertilization has positive impact on the growth of enlarged leaf surface area as well as the 
efficiency of Jerusalem artichoke's photosynthetic apparatus. This, however, refers to the end of the growing season and the leaf bottom layer of the tested plants.

The average value of the LAl indicator was slightly higher in the second year of study (Table 5). The application of sludge diminished the value of the parameter in relation to that obtained in the first year from 3.74 for the control variant to 2.98 in the variant with sludge fertilization. Similar patterns were also observed in the second year. The response of both cultivars to this factor was similar for both years of study. Biomass ash fertilization had positive impact in 2013, when increase in the tested feature was observed as far as the third level of fertilization $8.6 \mathrm{t} \cdot \mathrm{ha}^{-1}$. A further increase in the dosage to $12.8 \mathrm{t} \cdot \mathrm{ha}^{-1}$ did not affect any changes in the value of LAl index. The Albik cv. was characterized by denser foliage than Gigant cv., which amounted to about $23 \%$ and $28 \%$ in subsequent years, respectively. Similarly to features earlier described, no interactions between ash fertilization and cultivar or between sludge and ash fertilizations, were noted.

Table 5. Impact of sewage sludge (NO) and biomass ash fertilization (NP) on LAI $\left[\mathrm{m}^{2} \cdot \mathrm{m}^{-2}\right]$ of Jerusalem artichoke $(\mathrm{O})$ cultivars

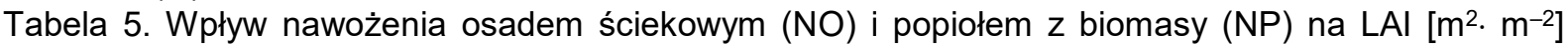
odmian (O) topinamburu

\begin{tabular}{|c|c|c|c|c|c|c|c|}
\hline \multirow{2}{*}{$\begin{array}{l}\text { Year } \\
\text { Lata }\end{array}$} & \multicolumn{2}{|c|}{ Factor - Czynnik } & \multicolumn{4}{|c|}{$\begin{array}{c}\text { Ash fertilization - Nawożenie popiołem } \\
{\left[\mathrm{t} \cdot \mathrm{ha}^{-1}\right]}\end{array}$} & \multirow{2}{*}{$\begin{array}{l}\text { Average } \\
\text { Średnia }\end{array}$} \\
\hline & $\begin{array}{c}\text { sludge - osad } \\
{\left[\mathrm{t} \cdot \mathrm{ha}^{-1}\right]}\end{array}$ & $\begin{array}{l}\text { cultivar } \\
\text { odmiana }\end{array}$ & 0 & 4.3 & 8.6 & 12.8 & \\
\hline \multirow{10}{*}{2013} & \multirow{3}{*}{0} & Gigant & 3.00 & 3.26 & 4.03 & 3.56 & 3.47 \\
\hline & & Albik & 3.28 & 4.39 & 4.43 & 3.99 & 4.02 \\
\hline & & $\begin{array}{l}\text { average } \\
\text { średnia }\end{array}$ & 3.14 & 3.83 & 4.23 & 3.78 & 3.74 \\
\hline & \multirow{3}{*}{30.3} & Gigant & 2.19 & 2.42 & 3.10 & 2.56 & 2.57 \\
\hline & & Albik & 3.38 & 3.12 & 3.67 & 3.40 & 3.39 \\
\hline & & $\begin{array}{l}\text { average } \\
\text { średnia }\end{array}$ & 2.78 & 2.77 & 3.39 & 2.98 & 2.98 \\
\hline & \multirow{2}{*}{ average - średnia } & Gigant & 2.60 & 2.84 & 3.57 & 3.06 & 3.02 \\
\hline & & Albik & 3.33 & 3.76 & 4.05 & 3.70 & 3.71 \\
\hline & \multicolumn{2}{|c|}{ total average - średnia ogólna } & 2.96 & 3.30 & 3.81 & 3.38 & 3.36 \\
\hline & \multicolumn{2}{|c|}{$\mathrm{HSD}_{0.05}$ for $-\mathrm{HSD}_{0,05} \mathrm{dla}$} & $\mathrm{NO}-0$. & $2-0$ & -0.573 & $\mathrm{NO}-\mathrm{n} . \mathrm{s}$ & \\
\hline \multirow{10}{*}{2014} & \multirow{3}{*}{0} & Gigant & 3.00 & 3.30 & 3.90 & 3.40 & 3.40 \\
\hline & & Albik & 4.30 & 4.40 & 4.50 & 4.20 & 4.35 \\
\hline & & $\begin{array}{l}\text { average } \\
\text { średnia }\end{array}$ & 3.65 & 3.85 & 4.20 & 3.80 & 3.88 \\
\hline & \multirow{3}{*}{30.3} & Gigant & 3.00 & 2.90 & 2.90 & 2.70 & 2.88 \\
\hline & & Albik & 3.90 & 3.70 & 3.50 & 3.60 & 3.68 \\
\hline & & $\begin{array}{l}\text { average } \\
\text { średnia }\end{array}$ & 3.45 & 3.30 & 3.20 & 3.15 & 3.28 \\
\hline & \multirow{2}{*}{ average - średnia } & Gigant & 3.00 & 3.10 & 3.40 & 3.05 & 3.14 \\
\hline & & Albik & 4.10 & 4.05 & 4.00 & 3.90 & 4.01 \\
\hline & \multicolumn{2}{|c|}{ total average - średnia ogólna } & 3.55 & 3.58 & 3.70 & 3.48 & 3.58 \\
\hline & \multicolumn{2}{|c|}{$\mathrm{HSD}_{0.05}$ for $-\mathrm{HSD}_{0,05} \mathrm{dla}$} & $\mathrm{NO}-0$. & $D-n$ & 476, & - n.s. & \\
\hline
\end{tabular}

n.s. - not significant difference - różnica nieistotna.

\section{Chlorophyll content in leaves (greenness index) - SPAD}

Measurements of chlorophyll fluorescence that largely replace conventional methods of measuring the photosynthesis rates are highly sensitive tests for plant's photosynthetic reactions (Demming and Bjórkman 1987). Measurements of chlorophyll fluorescence by induction enables the evaluation of energy utilization efficiency during light stage of photosynthesis and also indicates the quality of bonding between the photochemical phase 
and enzymatic photosynthesis phase, i.e. the assimilation of $\mathrm{CO}_{2}$. It is also a useful technique that enables in vivo monitoring of the impact of various stress factors on the photosynthetic process (Maxwell and Johnson 2000; Ell and Toivonen 2003; Kuckenberg et al. 2009).

Sawicka and Michałek (2005) conducted the evaluation of the photosynthetic activity of the leaves of Jerusalem artichoke cultivated on rye good soils by means of the measurements of fluorescence induction. The Fv/Fm parameter value of 0.783 for the Albik cv. is considered by the authors as favorable and confirms the huge potential efficiency of photosystem II, and therefore the productive potentials of the Jerusalem artichokes being tested.

The average value of greenness index SPAD varied over the subsequent years of study (Table 6). Values in 2013 were slightly higher than in 2014. No significant differences in the parametric values of the fluorescence were observed in the current studies, although they were high and ranged from 0.764 to 0.803 . Fertilization with biomass ash contributed to intensified coloration of leaves in 2013 . The value of SPAD increased by 1.8 units along with the increase in fertilizer dosage from 0 to $12.8 \mathrm{t} \cdot \mathrm{ha}^{-1}$. No significant differences were observed in the subsequent year. The highest differences were recorded between cultivars. The Gigant cv. had much less intensified coloration than the Albik cv. The difference was about $10 \%$ and remained stable regardless of prevailing weather conditions in subsequent years. This indicates that Jerusalem artichoke plants have characteristically high efficiency of photochemical processes in the light phase of photosynthesis, thus reflecting the suitability of the species for cultivation in soils fertilized with sewage sludge and biomass ash.

Table 6. Impact of sewage sludge (NO) and biomass ash (NP) fertilization on SPAD (ju) of Jerusalem artichoke $(\mathrm{O})$ cultivars

Tabela 6. Wpływ nawożenia osadem ściekowym (NO) i popiołem z biomasy (NP) na SPAD (ju) odmian (O) topinamburu

\begin{tabular}{|c|c|c|c|c|c|c|c|}
\hline \multirow{2}{*}{$\begin{array}{l}\text { Year } \\
\text { Rok }\end{array}$} & \multicolumn{2}{|c|}{ Factor - Czynnik } & \multicolumn{4}{|c|}{$\begin{array}{l}\text { Ash fertilization - Nawożenie popiołem } \\
{\left[\mathrm{t} \cdot \mathrm{ha}^{-1}\right]}\end{array}$} & \multirow{2}{*}{$\begin{array}{l}\text { Average } \\
\text { Średnia }\end{array}$} \\
\hline & $\begin{array}{c}\text { sludge - osad } \\
{\left[\mathrm{t} \cdot \mathrm{ha}^{-1}\right]}\end{array}$ & $\begin{array}{l}\text { cultivar } \\
\text { odmiana }\end{array}$ & 0 & 4.3 & 8.6 & 12.8 & \\
\hline \multirow{10}{*}{2013} & \multirow[t]{3}{*}{ 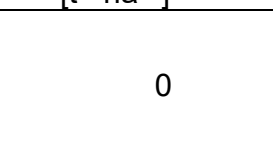 } & Gigant & 29.0 & 28.3 & 29.3 & 30.7 & 29.3 \\
\hline & & Albik & 37.6 & 41.2 & 41.4 & 41.1 & 40.3 \\
\hline & & $\begin{array}{l}\text { average } \\
\text { średnia }\end{array}$ & 33.3 & 34.8 & 35.4 & 35.9 & 34.8 \\
\hline & \multirow{3}{*}{30.3} & Gigant & 28.6 & 28.9 & 28.3 & 28.9 & 28.7 \\
\hline & & Albik & 37.7 & 37.2 & 38.8 & 39.6 & 38.3 \\
\hline & & $\begin{array}{l}\text { average } \\
\text { średnia }\end{array}$ & 33.2 & 33.1 & 33.5 & 34.3 & 33.5 \\
\hline & \multirow{2}{*}{ average - średnia } & Gigant & 28.8 & 28.6 & 28.8 & 29.8 & 29.0 \\
\hline & & Albik & 37.7 & 39.2 & 40.1 & 40.3 & 39.3 \\
\hline & \multicolumn{2}{|c|}{ total average - średnia ogólna } & 33.3 & 33.9 & 34.5 & 35.1 & 34.2 \\
\hline & \multicolumn{2}{|c|}{$\mathrm{HSD}_{0.05}$ for $-\mathrm{HSD}_{0,05}$ dla } & $\mathrm{NO}-\mathrm{n}$. & -1.6 & $1.51, \mathrm{C}$ & n.s. & \\
\hline \multirow{10}{*}{2014} & \multirow{3}{*}{0} & Gigant & 24.8 & 23.6 & 24.4 & 24.2 & 24.3 \\
\hline & & Albik & 33.6 & 32.1 & 32.5 & 35.4 & 33.4 \\
\hline & & $\begin{array}{l}\text { average } \\
\text { średnia }\end{array}$ & 29.2 & 27.8 & 28.5 & 29.8 & 28.8 \\
\hline & \multirow{3}{*}{30.3} & Gigant & 26.3 & 25.1 & 25.2 & 24.3 & 25.2 \\
\hline & & Albik & 34.4 & 33.9 & 31.8 & 33.7 & 33.4 \\
\hline & & $\begin{array}{l}\text { average } \\
\text { średnia }\end{array}$ & 30.4 & 29.5 & 28.5 & 29.0 & 29.3 \\
\hline & \multirow{2}{*}{ average - średnia } & Gigant & 25.6 & 24.4 & 24.8 & 24.2 & 24.7 \\
\hline & & Albik & 34.0 & 33.0 & 32.1 & 34.6 & 33.4 \\
\hline & \multicolumn{2}{|c|}{ total average - średnia ogólna } & 29.8 & 28.7 & 28.5 & 29.4 & 29.1 \\
\hline & \multicolumn{2}{|c|}{$\mathrm{HSD}_{0.05}$ for $-\mathrm{HSD}_{0,05}$ dla } & $\mathrm{NO}-\mathrm{n}$. & - n.s. & $61, \mathrm{O} /$ & h.s. & \\
\hline
\end{tabular}

n.s. - not significant difference - różnica nieistotna. 


\section{Induced chlorophyll fluorescence Fv/Fm}

The efficiency of light utilization expressed as Fv/Fm ratio was comparable for both years (Table 7). Fertilization with sludge did not provoke significant differences in the ratio of variable fluorescence to the maximum in both years. The lack of response of cultivars to the varied levels of sludge fertilization clearly indicates similar responses of tested cultivars. Biomass ash fertilization resulted in minimal, yet steady increase of the Fv/Fm index relative to doses applied through the first year of study. No significant differences were observed in the second year, while changes regarding the average values were incidental in nature. Comparisons of average values for the main cultivar show that Albik cv. attained higher values. The differences were, however, only statistically proven in the first year of study.

Table 7. Impact of sewage sludge (NO) and biomass ash (NP) fertilization on Fv/Fm ratio of Jerusalem artichoke (O) cultivars

Tabela 7. Wpływ nawożenia osadem ściekowym (NO) i popiołem z biomasy (NP) na Fv/Fm odmian (O) topinamburu

\begin{tabular}{|c|c|c|c|c|c|c|c|}
\hline \multirow{2}{*}{$\begin{array}{l}\text { Year } \\
\text { Rok }\end{array}$} & \multicolumn{2}{|c|}{ Factor - Czynnik } & \multicolumn{4}{|c|}{$\begin{array}{l}\text { Ash fertilization - Nawożenie popiołem } \\
{\left[\mathrm{t} \cdot \mathrm{ha}^{-1}\right]}\end{array}$} & \multirow{2}{*}{$\begin{array}{l}\text { Average } \\
\text { Średnia }\end{array}$} \\
\hline & $\begin{array}{c}\text { sludge - osad } \\
{\left[\mathrm{t} \cdot \mathrm{ha}^{-1}\right]}\end{array}$ & $\begin{array}{l}\text { cultivar } \\
\text { odmiana }\end{array}$ & 0 & 4.3 & 8.6 & 12.8 & \\
\hline \multirow{10}{*}{2013} & \multirow[t]{3}{*}{$\begin{array}{llll} & 1 \\
\end{array}$} & Gigant & 0.797 & 0.780 & 0.750 & 0.730 & 0.764 \\
\hline & & Albik & 0.850 & 0.800 & 0.790 & 0.800 & 0.810 \\
\hline & & $\begin{array}{l}\text { average } \\
\text { średnia }\end{array}$ & 0.823 & 0.790 & 0.770 & 0.765 & 0.787 \\
\hline & \multirow{3}{*}{30.3} & Gigant & 0.820 & 0.800 & 0.810 & 0.750 & 0.795 \\
\hline & & Albik & 0.810 & 0.833 & 0.840 & 0.830 & 0.828 \\
\hline & & $\begin{array}{l}\text { average } \\
\text { średnia }\end{array}$ & 0.815 & 0.817 & 0.825 & 0.790 & 0.812 \\
\hline & \multirow{2}{*}{ average - średnia } & Gigant & 0.808 & 0.790 & 0.780 & 0.740 & 0.780 \\
\hline & & Albik & 0.830 & 0.817 & 0.815 & 0.815 & 0.819 \\
\hline & \multicolumn{2}{|c|}{ total average - średnia ogólna } & 0.819 & 0.803 & 0.798 & 0.778 & 0.799 \\
\hline & \multicolumn{2}{|c|}{$\mathrm{HSD}_{0.05}$ for $-\mathrm{HSD}_{0,05}$ dla } & \multicolumn{4}{|c|}{$\mathrm{NO}-$ n.s., NP - 0.038, O - n.s., O/NO - n.s. } & \\
\hline \multirow{10}{*}{2014} & \multirow{3}{*}{0} & Gigant & 0.783 & 0.750 & 0.770 & 0.760 & 0.766 \\
\hline & & Albik & 0.800 & 0.820 & 0.790 & 0.780 & 0.798 \\
\hline & & $\begin{array}{l}\text { average } \\
\text { średnia }\end{array}$ & 0.792 & 0.785 & 0.780 & 0.770 & 0.782 \\
\hline & \multirow{3}{*}{30.3} & Gigant & 0.770 & 0.740 & 0.780 & 0.750 & 0.760 \\
\hline & & Albik & 0.810 & 0.820 & 0.800 & 0.780 & 0.803 \\
\hline & & $\begin{array}{l}\text { average } \\
\text { średnia }\end{array}$ & 0.790 & 0.780 & 0.790 & 0.765 & 0.781 \\
\hline & \multirow{2}{*}{ average - średnia } & Gigant & 0.777 & 0.745 & 0.775 & 0.755 & 0.763 \\
\hline & & Albik & 0.805 & 0.820 & 0.795 & 0.780 & 0.800 \\
\hline & \multirow{2}{*}{\multicolumn{2}{|c|}{ total average - średnia ogólna }} & 0.791 & 0.783 & 0.785 & 0.768 & 0.781 \\
\hline & & $\mathrm{HSD}_{0.05}$ for $-\mathrm{HSD}_{0,05}$ dla & $\mathrm{NO}-\mathrm{n} . \mathrm{s}$ & - n.s., & ר.s., $\mathrm{O} / \mathrm{\Gamma}$ & n.s. & \\
\hline
\end{tabular}

n.s. - not significant difference - różnica nieistotna.

\section{Correlation and regression between yield and biometric features of plants}

The simple correlation coefficient $r$ of linear regression equation in instances, for which significant dependence was confirmed, is presented in Table 8.

The strongest correlation (at $\alpha=0.001$ ) during the first year was found between dry matter yield and plants' height. A positive, significant correlation between the LAI and SPAD was also confirmed. There was a lack of dependence between dry matter yields and shoot diameter as well as the Fv/Fm index. Values of the correlation coefficients were 0.342 and 0.218 , respectively. 
Significant correlation between yields and plant's height, including the SPAD (a very high significant dependence) were, however observed in the second year. Although the dependence between yield and LAI index was not significant at 0.05 level, it was positive and rather distinctive $(r=0.411)$, and higher than the critical value at 0.10 level thus meaning that the risk of error was less than $10 \%$, having rejected $\mathrm{H}_{\circ}$ that assumes the lack of dependence. Additionally, a statistical dependence between yields and the Fv/Fm index was confirmed. It thus indicates that dry matter yield was correlated mainly with the plants' height and chlorophyll content in leaves (SPAD).

Table 8. Evaluating the dependence between Jerusalem artichoke yields (dry weight) and parameters of the crop pattern as well as the biometric features during 2013 and $2014(n=16)$

Tabela 8. Ocena zależności pomiędzy plonem topinamburu (sucha masa) a parametrami struktury łanu i cechami biometrycznymi w latach 2013 i $2014(n=16)$

\begin{tabular}{|c|c|c|c|c|}
\hline $\begin{array}{l}\text { Year } \\
\text { Rok }\end{array}$ & Feature - Cecha & $\begin{array}{c}\text { Correlation } \\
\text { coefficient r } \\
\text { Współczynik } \\
\text { korelacji r }\end{array}$ & $\begin{array}{l}\text { Significance } \\
\text { Istotność }\end{array}$ & $\begin{array}{l}\text { Regression equation } \\
\text { Równanie regresji }\end{array}$ \\
\hline \multirow{5}{*}{2013} & $\begin{array}{l}\text { plant height } \\
\text { wysokość roślin [m] }\end{array}$ & 0.873 & $* * *$ & $y=-6.98+6.104 x$ \\
\hline & $\begin{array}{l}\text { shoot diameter } \\
\text { średnica pędu [cm] }\end{array}$ & 0.342 & - & - \\
\hline & $\mathrm{LAI}\left[\mathrm{m}^{2} \cdot \mathrm{m}^{-2}\right]$ & 0.619 & * & $y=0.132+1.084 x$ \\
\hline & SPAD (ju) & 0.525 & * & $y=0.056+0.109 x$ \\
\hline & $\mathrm{F}_{\mathrm{v}} / \mathrm{F}_{\mathrm{m}}$ & 0.218 & - & - \\
\hline \multirow{5}{*}{2014} & $\begin{array}{l}\text { plant height } \\
\text { wysokość roślin [m] }\end{array}$ & 0.614 & * & $y=0.742+3.049 x$ \\
\hline & $\begin{array}{l}\text { shoot diameter } \\
\text { średnica pędu [cm] }\end{array}$ & -0.522 & * & $y=18.94-9.772 x$ \\
\hline & $\mathrm{LAI}\left[\mathrm{m}^{2} \cdot \mathrm{m}^{-2}\right]$ & 0.411 & - & - \\
\hline & SPAD (ju) & 0.846 & $\star * * *$ & $y=-5.52+0.426 x$ \\
\hline & $\mathrm{F}_{\mathrm{v}} / \mathrm{F}_{\mathrm{m}}$ & 0.660 & $* *$ & $y=-41.86+62.50 x$ \\
\hline
\end{tabular}

„-" - not significant dependence - zależność nieistotna, *significant dependence $(\alpha=0.05)$ - zależność istotna $(p=0,05),{ }^{* *}$ high significant dependence $(\alpha=0.01)$ - zależność wysokoistotna $(\alpha=0,01),{ }^{* * *}$ very high significant dependence $(\alpha=0.001)$ - zależność bardzo wysokoistotna $(\alpha=0,001)$.

\section{CONCLUSIONS}

1. The application of sewage sludge at the rate of $30.3 \mathrm{t} \cdot \mathrm{ha}^{-1}$ had impact on the yield of Jerusalem artichoke in subsequent years of study. The yield following the first year of application was about $0.8 \mathrm{t}$ lower, while the response to sludge fertilization in the second year was positive. Differences in yield levels under varied levels of fertilization with sewage sludge depended on the length of shoots as well as the LAI and SPAD.

2. Biomass ash fertilization resulted in systematic increase in yields of the vegetative (aerial) parts in 2013. Although differences in yields in the following year were negligible, tendencies towards increase of the increased length of shoots, were observed. Yield increase of Jerusalem artichoke fertilized with biomass ash was associated with increased length of shoots, increasing values of the LAI and SPAD.

3. There was no significant interaction between the organic (sludge) and mineral fertilization, which proves that yield variations following ash fertilization were the same regardless of the sludge variant. 
4. The Albik cv. was, amongst the two tested (Polish Albik and Dutch Gigant), characterized by higher yields. If, however, the average yields obtained in the second year using sewage sludge were taken into consideration, the differences were found to be much less. Gigant $\mathrm{cv}$. is a cultivar with much higher demands for fertilization than Albik cv. The Polish Albik $\mathrm{CV}$. was characterized by greater shoot lengths, less shoot diameters, higher LAI index, and much higher SPAD (cultivar related features) value, while the Fv/Fm index for both cultivars was similar.

\section{REFERENCES}

Augustynowicz J., Pietkiewicz S., Kalaji M.H., Russel S. 2010. Wpływ nawożenia osadem ściekowym na wybrane parametry aktywności biologicznej gleby oraz wydajności aparatu fotosyntetycznego słonecznika bulwiastego (Helianthus tuberosus L.) [Microbiological status of soil and the efficiency of photosynthetic apparatus of the Jerusalem artichoke (Helianthus tuberosus L.) fertilised with sludge from wastewater treatment plant]. Woda Środ. Obsz. Wiej. 10, 2(30), 7-18. [in Polish]

Bakisgan C., Dumanli A.G., Yurum Y. 2007. Trace elements in Turkish biomass fuels: Ashes of wheat straw, olive bagasse and hazelnut shell. Fuel 88, 1842-1851.

Chołuj D., Podlaski S., Wiśniewski G., Szmalec J. 2008. Kompleksowa ocena biologicznej przydatności 7 gatunków roślin wykorzystywanych na cele energetyczne. [A comprehensive assessment of the biological usefulness of 7 plant species cultivated for energy purposes]. Stud. Repor. IUNG-PIB Puławy 11, 82-99. [in Polish]

Ciesielczuk T., Kusza G., Nemś A. 2011. Nawożenie popiołami z termicznego przekształcania biomasy źródłem pierwiastków śladowych dla gleb [Fertilization with ash sourced from the thermal conversion of biomass as a source of trace elements in soils]. Ochr. Śr. Zas. Natur. 49, 219-227. [in Polish]

Demming B., Bjórkman O. 1987. Comparison of the effect of excessive light on chlorophyll fluorescence $(77 \mathrm{~K})$ and photon yield of $\mathrm{O}_{2}$ evolution in leaves of higher plants. Planta 171, 171-184. [in Polish]

EII J.R., Toivonen P.M.A. 2003. Practical applications of chlorophyll fluorescence in plant biology. Dordrecht, Kluver Academic Publishers.

Gibczyńska M., Meller E., Stankowski S., Prokopowicz A. 2009. Wpływ popiołów z węgla brunatnego na skład chemiczny gleby lekkiej [Effect of brown coal ash on chemical properties of light soil]. Zesz. Probl. Post. Nauk Rol. 538, 63-71. [in Polish]

Góral S. 1999. Słonecznik bulwiasty - topinambur. Uprawa i użytkowanie [Artichoke - Jerusalem artichoke. Cultivation and use]. Radzików, IHAR. [in Polish]

Góral S. 1999a. Wartość użytkowa topinamburu (Helianthus tuberosus L. [The utility value of Jerusalem artichoke (Helianthus tuberosus L.)]. Zesz. Probl. Post. Nauk Rol. 468, 89-94. [in Polish]

James A.K., Thring R. W., Helle S., Ghuman H.S. 2012. Ash management review-applications of biomass bottom ash. Energies 5, 3856-3873.

Kalembasa D., Malinowska E. 2007. Wpływ dawek osadu ściekowego na plon i skład chemiczny trawy Miscanthus sacchariflorus [The influence of waste activated sludge doses on the yield and chemical composition of Miscanthus sacchariflorus grass]. Fragm. Agron. 1(93), 113-118. [in Polish]

Klimont K. 2004. Przydatność wybranych gatunków roślin użytkowych do rekultywacji terenów zdewastowanych [Application of some useful plants in soil reclamation]. Zesz. Probl. Post. Nauk Rol. 497, 673-684. [in Polish]

Klimont K., Bulińska-Radomska Z. 2008. Przydatność wybranych gatunków roślin do rekultywacji podłoża wapna poflotacyjnego w rożnych warunkach agrotechnicznych [Usefulness of selected plant species to reclamation of the post-flotation lime substrate under various agrotechnical conditions]. Probl. Inż. Rol. 1, 99-106. [in Polish] 
Kuckenberg J., Tartachnyk I. Noga G. 2009. Temporal and spatial changes of chlorophyll fluorescence as a basis for early and precise detection of leaf rust and powdery mildew infections in wheat leaves. Precis. Agric. 10(1), 34-44.

Kuś J., Faber A. 2009. Produkcja roślinna na cele energetyczne a racjonalne wykorzystanie rolniczej przestrzeni produkcyjnej Polski, w: I Kongres Nauk Rolniczych. Nauka - Praktyce, Puławy 14-15 maja 2009. Puławy, IUNG, 63-75. [in Polish]

Maxwell K., Johnson G.N. 2000. Chlorophyll fluorescence - a practical guide. J. Experim. Bot. 51(345), 659-668.

Meller E., Niedźwiecki E., Wojcieszczuk T., Jarnuszewski G. 2009. Porównanie właściwości fizykochemicznych popiołów po spaleniu biomasy o zróżnicowanym składzie [Comparison of physico-chemical properties of the ashes from incineration of different biomass materials]. Zesz. Probl. Post. Nauk Rol. 535, 297-303. [in Polish]

Meller E., Bilenda E. 2012. Wpływ popiołów ze spalania biomasy na właściwości fizykochemiczne gleb lekkich [Impacts of ash from biomass combustion on the physical and chemical properties of light soils]. Polit. Energ. 15(3), 287-292. [in Polish]

Piekarczyk M., Kotwica K., Jaskulski D. 2011. W pływ stosowania popiołu ze słomy jęczmienia jarego na chemiczne właściwości gleby lekkiej [Effect of spring barley straw ash on the chemical properties of light soil]. Fragm. Agron. 28(3), 91-99. [in Polish]

Piekarczyk M. 2013. Zawartość przyswajalnych form niektórych makro- i mikroelementów w glebie lekkiej nawożonej popiołem ze słomy pszenicy ozimej [Effect of winter wheat straw ash on the some macro- and microelements available forms content in light soil]. Fragm. Agron. 30(1), 92-98. [in Polish]

Piskier T. 2006. Nakłady robocizny i koszty uprawy topinamburu [Labour inputs and costs of topinambour growing]. Inż. Rol. 11, 359-365. [in Polish]

Piskier T. 2009. Wykorzystanie kompostu z osadu ściekowego w uprawie topinamburu [Sludge compost use for topinambour growing]. Inż. Rol. 9(118), 189-195 [in Polish]

Piskier T., Sekutowski T. 2013. Ze stołu do pieca [From the table to the stove]. Agroenergetyka 1, 38-41. [in Polish]

Sawicka B., Michałek W. 2005. Evaluation and productivity of Helianthus tuberosus L. in the conditions of Central-East Poland. Electr. J. Pol. Agric. Univ., Horticulture 8(3), www.ejpau.media.pl, access: 7.12.2016.

Stankowski S., Hury G., Gibczyńska M., Jurgiel-Małecka G. 2014. Wpływ stosowania wapna, popiołu z biomasy i kompostu oraz preparatu EM na plonowanie i komponenty plonu pszenicy [Impacts of use of lime, biomass ash and compost as well as EM preparations on the yield and yield components of wheat]. Inż. Ekol. 38, 17-25. [in Polish]

Szulc W., Rutkowska B. 2002. Ocena możliwości wykorzystania w rolnictwie osadu ściekowego z miejskiej oczyszczalni ścieków [Assessing possibilities of agricultural use of sewage sludge from municipal sewage treatment plants]. Acta Agrophys. 70, 317-323. [in Polish]

Włodek S. 2007. Możliwość wykorzystania ścieków i osadów ściekowych w uprawie roślin energetycznych [Possibilities of use of wastewater and sludge in the cultivation of plants for Energy purposes]. Stud. Rapor. IUNG-PIB Puławy 8, 208-216. [in Polish]

Abstract. Jerusalem artichoke is one of such plants that can be put to energy use. The objective of the research study was to assess the impact of fertilization with sewage sludge and conifer sourced ash biomass on yields as well as biometric and physiological parameters of two cultivars (Albik and Gigant) of Jerusalem artichoke (Helianthus tuberosus L.). The two-year study was carried out in fields located in Ujkowice near Przemyśl. The trials covered 3 factors, as follows: 4 levels of fertilization with biomass - ash from conifers, 2 levels of fertilization with sewage sludge, 2 cultivars of Jerusalem artichoke (Helianthus tuberosus L.) - Gigant and Albik. In the first year after the application of sewage sludge in an amount of $30.3 \mathrm{t} \cdot \mathrm{ha}^{-1}$, the yield was lower 
by about $0.8 \mathrm{t}$ and in the second, the reaction to fertilization using sludge was positive. Differences in yield under varied levels of fertilization with sewage sludge depended on the length of shoots as well as the LAI and SPAD indicators. Biomass ash fertilization resulted in systematic increase in yields of the vegetative (aerial) parts in 2013. In the subsequent year, differences were insignificant. Yield increase in Jerusalem artichoke fertilized with biomass ash was associated with increased lengths of shoots, increasing values of the LAI and SPAD. There was no significant interaction between the organic and mineral fertilization. Amongst the two tested, Albik cv. was characterized by higher yields. The Polish Albik cv. was characterized by higher shoot lengths, smaller shoot diameters, higher LAI index, and a much higher SPAD (cultivar related features) value, while the Fv/Fm index for both cultivars was similar. 
